DOI $10.31651 / 2524-2660-2019-1-46-50$

ORCID ID 0000-0001-6221-9196

\title{
ПАРХОМЕНКО Ірина Вомодимирівна,
}

Аспірантка, Сумський державний педагогічний університет імені А.С.Макаренка e-mail: parkhomenkoiv@ukr.net

УДК 374.091:[94:908](471.52/.54)

\section{ЗМІНИ У ЗМІСТІ ІСТОРИКО-КРАСЗНАВЧОЇ РОБОТИ У ЗАКААДАХ ПОЗАШКІАЬНОЇ ОСВІТИ ПІВНІЧНО-СХІДНОЇ УКРАЇНИ}

У статті розкрито питання зміни у змісті історико-краєзнавчої роботи закладів позашкільної освіти Сумської, Харківської та Чернігівської областей за сучасних умов. Основними характерними особливостями иього проиесу визначено оновлення нормативних засад діяльності закладів позашкільної освіти, основних навчальних програм з позашкільної освіти туристсько-краєзнавчого напряму.

ключові слова: нормативно-правова база, програмне забезпечення, заклади позашкільної освіти, історико-краєзнавча робота, туристсько-краєзнавчий напрям.

Постановка проблемн. Серед чисменних закладів освіти, що відповідають за формування вмінь і навичок за інтересами, забезпечують потреби особистості у творчій самореалізації та фізичному, духовному та інтелектуальному розвитку засадниче місце відводиться закладам позашкільної освіти. У час реформування освітньої галузі вкрай важиивим є процес вдосконалення освітнього простору у цих закладах.

Сучасний стан педагогічної науки змушує досліджувати цей процес не $\Lambda$ ше в контексті виховання та творчого розвитку особистості, а й, передусім, перегляду нормативно-правової бази та навчальних програм закладів позашкільної освіти не мише загальнодержавного, а й регіонального рівня/ Зокрема актуальним сьогодні $є$ вивчення змістових засад діяльності сучасних закладів позашкільної освіти, а саме існуючої нормативно-правової, програмної бази та системи роботи гуртків та інших творчих об'єднань історико-краєзнавчого профілю.

Мета статті - дослідження процесу оновлення змістових засад історикокраєзнавчої роботи у закладах позашкільної освіти за сучасних умов, їх нормативного та програмного забезпечення на прикладі північно-східного регіону - Харківської, Сумської та Чернігівської областей.

Аналіз останніх досліджень i пубмікацій. Теоретичні засади нормативного та програмного забезпечення діяльності закладів позашкільної освіти відображенні у працях таких сучасних науковців та практиків як В.А. Маринич, Н.Ю. Давидюк , Р.А. Науменко, В.Є. Берека, А.В. Гуцоц, А.В. Тихенко, Н.В. Перепелиця, С.О Сьома, В.А. Редіна, М. Ю. Косимо тощо.

Так, зокрема, у дисертаційних роботах В.С. Береки та А.В. Гуцом досліджується нормативно-правове забезпечення діяльності закладів позашкільної Української РСР. Питанням врегулювання законодавчої та нормативно-правової системи України присвячені окремі аспекти наукових робіт В.А. Редіної та М.Ю. Косима.

Виклад основного матеріалу досмідження. Зміст історичного краєзнавства формується на основі таких базових понять як природне середовище, історичне минули та соціальна сфера, що мають територіальну єдність у межах певної мокації. Саме історико-краєзнавча робота є одним з засобів взаємодії з дитиною. Тому предметом нашої уваги $\epsilon$ особливості нормативного та програмного забезпечення діяльності закладів позашкільної освіти туристськокраєзнавчого напряму в розрізі трьох визначених областей.

Основною метою нормативно та програмного забезпечення позашкільної освіти є окреслення нормативних засад діяльності закладів позашкільної освіти, інших установ та організацій, визначення основних навчальних програм 3 позашкільної освіти туристськокраєзнавчого напряму.

3 огляду на регіональний характер нашого дослідження вважаємо доцільним видімити три групи нормативних документів.

Першу групу документів становцять розпорядження голів обласних, районних державних адміністрацій, міських виконавчих комітетів, рішення сесій обласних, міських, районних рад.

Концептуальними документами, що відображають специфіку розвитку освітньої галузі регіону є обласні програми розвитку освіти, головним завданням 
яких $€$ досягнення практичних результатів щодо зростання ефективності, доступності та підвищення якості освіти різного рівня. Такі обцасні програми впроваджується скоординованими діями місцевих органів виконавчої вцади, у першу чергу органів управціння освітою, та органів місцевого самоврядування у межах їх повноважень.

Обласна комплексна програма "Освіта Сумщини у 2016-2018 роках", затверджена рішенням Сумської обласної ради від 25 березня 2016. року та Обласна програма розвитку освіти "Новий освітній простір Харківщини" на 2019-2023 роки, затверджена рішенням Харківської обласної ради від 6 грудня 2018 року мають спільні риси та деякі регіональні особливості.

Спільною проблемою дия двох областей у сфері позашкільної освіти є збереження та розвиток мережі закладів позашкільної освіти, модернізація матеріально-технічної, навчальнометодичної бази закладів позашкімьної освіти, створення сприятиивих умов дмя розвитку обдарованих дітей, забезпечення доступності позашкільної освіти у сільській місцевості через роботу пересувних закладів позашкільної освіти. [1; 2]

Актуальними проблемами, що знайшии своє відображення у міських цільових програмах (Програма розвитку освіти м. Чернігова "Освіта в житті нашого міста" на 2017-2021 роки, затверджена рішенням Чернігівської міської ради від 27 жовтня 2016 року, Комплексна програма розвитку освіти м. Харкова на 2018-2022 роки, затверджена рішенням Харківської міської ради від 8 мистопада 2017 року)., крім вищезазначених, є вирішення питання про видімення нових та збереження існуючих приміщень для організації гурткової роботи 3 дітьми та учнівською молоддю, вивчення, узагальнення та поширення досвіду роботи закладів позашкільної освіти. [3; 4]

Серед інших обласних цільових програм також нашої уваги заслуговує Обмасна цільова комплексна програма "Момодь Сумщини на 2016-2020 роки", затверджена рішенням Сумської обласної ради від 25 березня 2016 року, у якій окреме місце відведене саме історикокраєзнавчій роботі 3 дітьми. Зокрема, відзначена потреба в організації та проведенні екскурсійних та експедиційних поїздок учнівської та студентської молоді історичними маршрутами Сумської обмасті та України, проведенні обласних краєзнавчих масових заходів дия дітей та учнівської момоді. [5].

Дотичними до предмету нашого дослідження є цільові програми вказаних областей з оздоровцення та відпочинку, сталого розвитку туризму, військовопатріотичного та національнопатріотичного виховання тощо.

До другої групи нормативних документів ми відносимо накази, мисти, поможення, статути, інформації, протоколи методичних та педагогічних рад, плани, звіти профільних та комплексних закладів позашкільної освіти різного рівня.

Історико-краєзнавча робота 3 дітьми та учнівською молоддю є прерогативою закладів позашкільної освіти передовсім туристсько-краєзнавчого напряму, але реалізовується опосередковано і у профільних закладах інших напрямів позашкільної освіти та комплексних закладах позашкільної освіти обласного, міського, районного, сільського (селищного) рівня (Плаци, Центри, Будинки позашкімьної освіти, дитячої та юнацької творчості тощо). Всі перераховані заклади знаходяться у безпосередньому підпорядкуванні органів управління освітою відповідного рівня.

У Харківській та Чернігівський областях саме обласні заклади позашкільної освіти туристсько-краєзнавчого напряму (Чернігівський обласний Центр дитячого та юнацького туризму i екскурсій, (з 2017 року - Комунальний позашкільний навчамьний заклад "Центр національно-патріотичного виховання, туризму та краєзнавства учнівської моцоді") та Харківська обласна станція юних туристів (з 2013 року - Комунальний заклад "Харківська обласна станція юних туристів" Харківської обласної ради") координують історико-краєзнавчу роботу з дітьми. [6; 7],

На території Сумської області за період української незалежності ситуація з обласною структурою-координатором такої роботи з дітьми докорінно змінимися. 31991 по 1997 рік функціонував профільний обласний заклад позашкільної освіти туристська-краєзнавчого напряму Сумська обласна станція юних туристів (з 1993 року Сумський обласний центр туризму, краєзнавства, екскурсій учнівської молоді). У 1997 році у наслідок зииття Сумського обласного центру туризму, краєзнавства та екскурсій учнівської молоді, Сумського обласного центру науково-дослідної та науково технічної творчості молоді, Сумської обмасної станції юних натуралістів було 
створено Сумський обласний центр позашкільної освіти та роботи з талановитою молоддю (з 2005 року комунальний заклад Сумської обласної ради - обласний центр позашкільної освіти та роботи 3 талановитою молоддю) [8]. Саме цей комплексний заклад є основним координатором в області різних напрямів позашкільної освіти, у тому числі туристсько-краєзнавчого напряму та історикокраєзнавчої роботи.

Програмне забезпечення історикокраєзнавчої роботи з дітьми становить третю групу документів, що визначають засадничі змістові засади взаємодії 3 дітьми під час вивчення історичного та інших видів краєзнавства.

Навчальні програми 3 позашкільної освіти туристсько-краєзнавчого напряму розроблені відповідно до норм Національної доктрини розвитку освіти та Закону України "Про позашкільну освіту".
Це документи нормативнорегламентуючого характеру, що визначають зміст навчамьного матеріалу, та вимоги до нього, методи та форми організації діяльності гуртків та інших творчих об'єднань закладів позашкільної освіти.

Освітня концепція навчальної програми розкриваються у пояснювальній записці. Також у ній подається коротка характеристика структури програми, ii окремих компонентів, особливостей організації навчально-виховного процесу, пропонуються основні форми та методи проведення занять тощо. У цьому розділі програми зазначаються вікові групи вихованців, їх кількісний склад.

Навчальні програми складаються відповідно до кваліфікаційних рівнів (початковий, основний, вищий) та розраховані на 1-3 роки роботи з дітьми.

Програми з позашкіцьної освіти туристсько-краєзнавчого напряму рекомендовані Міністерством освіти і науки України [9]

\begin{tabular}{|c|c|c|c|c|c|c|c|}
\hline \multirow{3}{*}{$\begin{array}{c}\text { Навчальна } \\
\text { програма }\end{array}$} & \multirow{3}{*}{ Рівень } & \multicolumn{2}{|c|}{ I рік навчання } & \multicolumn{2}{|c|}{ II рік навчання } & \multicolumn{2}{|c|}{ III рік навчання } \\
\hline & & \multicolumn{6}{|c|}{ Кількість годин (у тому числі) } \\
\hline & & теop. & практ. & теop. & практ. & Teop. & практ \\
\hline $\begin{array}{l}\text { "Юні туристи- } \\
\text { краєзнавці" }\end{array}$ & початковий & 52 & 164 & - & - & - & - \\
\hline $\begin{array}{l}\text { "Археологічне } \\
\text { краєзнавство" }\end{array}$ & основний & 76 & 140 & 76 & 140 & 80 & 136 \\
\hline $\begin{array}{l}\text { ("Географічне } \\
\text { краєзнавство" }\end{array}$ & основний & 56 & 160 & 78 & 138 & 64 & 152 \\
\hline $\begin{array}{l}\text { "Геологічне } \\
\text { краєзнавство" }\end{array}$ & основний & 56 & 160 & 68 & 148 & 70 & 146 \\
\hline $\begin{array}{l}\text { "Екологічне } \\
\text { краєзнавство" }\end{array}$ & основний & 56 & 160 & 50 & 166 & 50 & 166 \\
\hline $\begin{array}{l}\text { "Історичне } \\
\text { краєзнавство" }\end{array}$ & основний & 46 & 170 & 50 & 166 & 52 & 164 \\
\hline 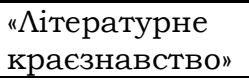 & основний & 54 & 162 & 58 & 158 & 58 & 158 \\
\hline
\end{tabular}

Основною програмою історикокраєзнавчої роботи з дітьми є навчальна програма для гуртків туристськокраєзнавчого напряму «Історичне краєзнавство" (автор Омельченко Д.Г., Савчук О.А.) рекомендована Міністерством освіти і науки України. [10]

У пояснювальній записці до програми «історичне краєзнавство" трактується як один з етапів пізнання вихованцями своєї малої Батьківщини, під час якого діти вивчають історичні, культурні надбання українського народу, збагачують свій світогляд, здобувають нові знання $з$ краєзнавства, закріплюють туристські вміння та навички засобами позашкільної освіти. Основною метою історико-краєзнавчої роботи $є$ набуття дитиною компетентностей у процесі вивчення історичного краєзнавства.

Враховуючі вікові та індивідуальні особливості вихованців, керівники гуртків, працюючи за програмами пропонованими Міністерством освіти і науки України, мають право вносити певні зміни щодо розподіму годин на вивчення окремих роздіків, послідовності викладу теоретичного матеріалу, проведення практичних занять.

Крім навчальних програм, рекомендованих Міністерством освіти і науки України, педагоги Сумської, Харківської та Чернігівської областей можуть користуватися у роботі навчальними програмами з позашкільної освіти туристськокраєзнавчого напряму, затвердженими на обласних рівнях Сумським обласним 
інститутом післядипломної педагогічної освіти, Харківським обласним науковометодичним інститутом безперервної освіти, Чернігівським обласним інститутом післядипломної педагогічної освіти відповідно.

Висновки та перспективи подамьших досміджень. Отже, оновлення та формування нормативно-правової та програмної бази історик-краєзнавчої роботи закладів позашкільної освіти - це скмадний багатоаспектний процес, що $є$ безпосередній маркером іiі змістових засад. Цей процес потребує вивчення та вдосконалення на основі врахування, 3 одного боку, науково-теоретичних досягнень педагогічної науки, а 3 іншого, потреб та викликів сучасної освітньої системи України.

Ми зробими спробу аналізу нормативно-правових документів та навчамьних програм, що окреслюють зміст, концептуальні напрями, структурноорганізаційні засади, засоби, форми, інші аспекти розвитку історикокраєзнавчої роботи у закладах позашкільної освіти Сумської, Харківської та Чернігівської областей.

\section{Cписок бібціографічних посниань}

1. Обласна комплексна програма "Освіта Сумщини y 2016-2018 pokax". URL: http://sm.gov.ua/uk/2012-02-03-08-03-13.html.

2. Обласна програми розвитку освіти "Новий освітній простір Харківщини" на 2019-2023 роки. URL: http://www.oblrada.kharkov.ua/ua/obla sna-programa-rozvitku-osviti-novij-osvitnij-prostirkharkivshchini-na-2014-2018-roki.

3. Комплексна програма розвитку освіти м. Харкова на 2018-2022 роки. URL: http: / / kharkiv.rocks / reestr/663865.

4. Програми розвитку освіти міста Чернігова "Освіта в житті нашого міста" на 2017-2021 роки. URL: http://www.chernigivrada.gov.ua/document/rishennya-sesii/10663.

5. Обласна цільова комплексна програма "Молодь Сумщини на 2016-2020 роки". URL: http://sm.gov.ua/uk/2012-02-03-08-03-13.html.

6. Рішення сесії Харківської обласної ради від 25.04.2013 року № 696-VI «Про перейменування Харківської обцасної станції юних туристів". URL: http: / / www.ts.lica.com.ua/b_text.php?type= 3\&id $=8441 \&$ base $=77$

7. Рішення сесії Чернігівської обласної ради від 23.02.2017 року № 26-8/VII «Про перейменування позашкільного навчального закладу "Центр дитячого та юнацького туризму i екскурсій".
URL: https:// chor.gov.ua/component/k2/item/49 69-pro-pereimenuvannia-pozashkilnohonavchalnoho-zakladu-tsentr-dyti.

8. Накази з основної діяльності. Том 2. ДАСО Ф-Р 3552, оп. 9, спр. 468, арк 178.

9. Програми позашкільної освіти: туристськокраєзнавчий напрям (випуск 1) Д.О. Бондарчук, O.C. Бондарчук, Н.I. Колодько та ін. / [упоряд. О.Д. Наровцянський, Д.Г. Омемьченко]. Київ, 2015. 134 c.

10. Мист Міністерства освіти і науки України від 14.07.2017 № 1/11-7083 «Про резумьтати науково-методичної експертизи". URL: http://ukrjuntur.org.ua/images/docs/Ist_kraev.jpg.

\section{References}

1. The Regional Integrated Program "Education of Sumy Region in 2016-2018". Retrieved from http://sm.gov.ua/uk/2012-02-03-08-03-13.html (application date 22.03.2019).

2. The regional educational development program "The New Educational Space of the Kharkiv Region" for 2019-2023 years. Retrieved from http: / / www.oblrada.kharkov.ua/ru/oblasnaprograma-rozvitku-osviti-novij-osvitnij-prostirkharkivshchini-na-2014-2018-roki (application date 22.03.2019).

3. Integrated program of education development in Kharkiv for 2018-2022 years. Retrieved from http://kharkiv.rocks/reestr/663865 (application date 22.03.2019).

4. Education programs of the city of Chernihiv "Education in the life of our city" for 2017-2021 years. Retrieved from http://www.chernigivrada.gov.ua/document/rishennya-sesii/10663 (application date 22.03.2019).

5. Oblast Target Complex Program "Youth of Sumy Region for 2016-2020". Retrieved from http: / / sm.gov.ua/uk/2012-02-03-08-03-13.html (application date 22.03.2019).

6. Decision of the session of the Kharkiv Regional Council dated 04.25.2013 No. 696-VI "On the renaming of the Kharkiv Regional Station for Young Tourists". Retrieved from http: / / www.ts.lica.com.ua/b_text.php?type=3\&id= 8441 \&base $=77$ (application date 22.03.2019).

7. Decision of the session of the Chernihiv Regional Council dated 23.02.2017 No. 26-8 / VII "On the Renaming of an Out-of-School Educational Establishment" Center for Child and Youth Tourism and Excursions". Retrieved from https://chor.gov.ua/component/k2/item/4969pro-pereimenuvannia-pozashkilnoho-navchalnohozakladu-tsentr-tida (application date 22.03.2019).

8. Orders from the main activities. Volume 2. SASO FR 3552, descript 9, folder 468, sh. 178.

9. Out-of-school education programs: tourist destination (issue 1) D.O. Bondarchuk, O.S. Bondarchuk, N.I. Kolodko and others. / [ordering. O.D. Narovlyansky, D.G. Omelchenko]. Kyiv, 2015. $134 \mathrm{p}$.

10. Letter of the Ministry of Education and Science of Ukraine dated 07/14/2017 No. 1 / 11-7083 "On the results of scientific and methodological expertise". $\quad$ Retrieved from http://ukrjuntur.org.ua/images/docs/Ist_kraev.jpg.

\section{PARKHOMENKO Iryna,}

postgraduate student, A.S. Makarenko State Pedagogical University at Sumy

\section{CHANGES IN THE CONTENT OF HISTORICAL AND LOCAL LORE WORK IN OUT-OF-SCHOOL ESTABLISHMENTS IN THE NORTH-EAST UKRAINE}

Abstract. Introduction. Modern social demand for creating conditions for the development of a versatile personality, the disclosure and realization of its creative potential is forcing researchers and practitioners to analyse deeply and improve the pedagogical technologies of the work of clubs and other creative associations of institutions of out-of-school education. In particular, today the study of the content principles of the activity of modern out-of-school educational institutions, namely, the existing regulatory and legal framework, and the system of work 
of circles and other creative associations of the historical and local lore profile, is a question of urgent importance today.

The purpose of the article is the investigation of the process of updating the content of the historical and local lore work in out-of-school educational establishments under the present-day conditions, their normative and programme supply in an imitation of the north-eastern region - Kharkiv, Sumy and Chernihiv regions.

The methods of the scientific research are generalization and comparison of normative acts, curricula, theoretical analysis of archival sources and methodical literature.

Results. The article analyzes the documents reflecting the specifics of the educational development of the three identified regions - regional educational development programs, one of the tasks of which is to achieve practical results in terms of increasing the efficiency, accessibility and quality of extracurricular education. On the basis of the analysis of program historical and ethnographic work, the main content and organizational principles of interaction with children were determined during the study of historical and other types of local lore studies in the conditions of out-of-school educational institutions.

Originality. The article deals with the questions of formation and updating of the normative and program basis of activities of non-school education institutions of Sumy, Kharkiv and Chernihiv regions.

Conclusion. Updating and forming the normative and legal base documents and studying programs of the historian and local lore work of institutions of out-ofschool education is a complex multidimensional process, which is a direct marker of its content principles. This process needs to be studied and improved paying attention to, on the one hand, the scientific and theoretical achievements of pedagogical science, and on the other, the needs of the modern educational system of Ukraine.

Keywords: legal basis; program implementation; out-of-school educational establishments; historical and ethnographic work; tourist local lore direction.

Одержано редакиією 12.01.2019 Прийнято до публікаиії 21.01.2019

DOI 10.31651/2524-2660-2019-1-50-54

ORCID 0000-0001-5455-4891

\section{ГЕРАСІмОВА Наталія Свгеніїна,}

кандидат психологічних наук, доцент кафедри педагогіки і психології,

Черкаський національний університет імені Богдана Хмельницького e-mail: gerasimovanata@ukr.net

ORCID 0000-0003-3981-1428

\section{ГЕРАСИМОВА Інна Вододимирівна,}

кандидат педагогічних наук, доцент кафедри педагогіки і психології, транзактний аналітик, Черкаський національний університет імені Богдана Хмельницького e-mail: inna_anni_0512@ukr.net

УДК 377.3

\section{ПСИХОАОГІЧНІ ЗАХИСТИ ЯК ЗАСІБ ВИРІШЕННЯ ВНУТРІШНЬООСОБИСТІСНИХ КОНФАIKTIB}

У статті розглядаються умови виникнення внутрішньоособистісних конфліктів з точки зору гуманістичної психологї. Досліджуються механізми захисту, які $\epsilon$ продуктами внутрішньоособистісних конфліктів. На підставі аналізу науково-психологічних джерел внутрішньоособистісний конфлікт визначається як інтрапсихічна і інтерпсихічна презентаиія назрілої суперечності, яка гранично загострена і вимагає свого зняття, а характер вирішення визначае спрямованість в розвитку індивіда. Механізми захисту, будучи продуктами внутрішньоособистісних конфліктів $i$ функиіонуючи несвідомо, можуть як сприяти, так $i$ перешкоджати ефективній адаптаиї індивіда в соиіумі.

Ключові слова: конфліктність; наслідки особистісної конфліктності; особистісні й ситуативні умови; психологічний захист.

Постановка проблеми. Аналіз відповідної зарубіжної психологічної мітератури приводить нас до висновку, що окремі концепції внутрішньоособистісного конфмікту базуються всередині розуміння відповідної мотиваційної модемі i не грунтуються на певній цілісній теорії. Вивчення однієї з особли- востей внутрішнього світу особистості суперечність його компонентів - дозвомими сформулювати універсальне уявмення про внутрішньоособистісний конфмікт як зіткнення одночасно актуалізо-

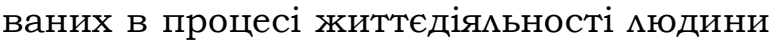
різнонаправ ених тенденцій, відносин тощо, а також співвіднести це уявцення з тими, що $є$ в сучасній психологічній мітературі поняттям внутрішнього конфмікту. Саме механізми психологічного захисту особистості являють собою спеціальну регулятивну систему стабілізації особистості, спрямовану на усунення або зведення до мінімуму почуття тривоги або страху, що супроводжують внутрішньоособистісний конфмікт. Механізми психологічного захисту є продуктом індивідуального життєвого

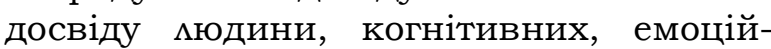
них, вольових стандартів поведінки, які формуються в процесі навчання і всієї життєдіяльності індивіда.

мета статті. З'ясування умов виникнення внутрішньоособистісного конфмікту в руслі гуманістичної психо- 